УДК 325.111(510)

\title{
Friendship Test: the "Chineseness" Drama in the Border City Conditions
}

Ivan Peshkov*

Uniwersytet im. Adama Mickiewicza w Poznaniu 1 Wieniawskiego Str., Poznań, 61-712, Poland

Received 18.10.2018, received in revised form 24.10.2018, accepted 07.11.2018

The author uses Manzhouli materials to analyse the role of frontier urbanization in the mass reflection as regards Chinese migration and China's role in the region. The analysis is based on two series of semi-formalized interviews (in 2013 and 2014) with city residents and tourists from Russia and China. The article shows that the success of cooperation in Siberian regions at the new stage of development requires reconsidering the existing mythologemes of the postSoviet consciousness, i.e. spatial (periphery is dependent on the centre), border (protection from Chinese migrants is needed) and economic (reliable cooperation is impossible) mythologemes.

Keywords: frontier urbanism, "Chineseness", disputed areas, migration.

Research area: sociology.

Citation: Peshkov, I. (2018). Friendship test: the "Chineseness" drama in the border city conditions. J. Sib. Fed. Univ. Humanit. soc. sci., 11(11), 1742-1761. DOI: 10.17516/1997-1370-0337.

Market space and border crossings points are most often associated with disorder.

Caroline Humphrey

The peculiarity of border urbanization at the Russian eastern border is due to the emergence of extraterritorial urban spaces that creatively connect prevailing socialist aesthetics and neoliberal hope for a better life in the region. These small factories of modernity and exchange, thanks to their situation and the conscious image of them as an ambivalent place (equally alien to both China and Russia), played a huge role in the mass reflection on the challenge of Chinese migration. In this regard, the cross-

(c) Siberian Federal University. All rights reserved

* Corresponding author E-mail address: i.peshkov@wp.pl

This work is licensed under a Creative Commons Attribution-NonCommercial 4.0 International License (CC BY-NC 4.0). 
border localization had to include the practice of "our appropriation of China" in the general tendency to feel the Chinese presence in the region, therefore this trend is of interest not only for the research on Chinese-style frontier urbanization, but also for entwinement of projections about and experience in complicated relations between the host society and Chinese migrants.

The main topic of the article includes explicit and implicit views of Russian crossborder entrepreneurs on how an Asian trade city, which is convenient for business and leisure purposes, should look like. According to Russian respondents, the criteria for the border trade city, which is convenient for business and leisure are obvious: for advantageous trading there should be a combination of relative safety, low prices for goods and a critical mass of Russian-speaking entrepreneurs. Not everything is as simple as it seems at first glance though. The border Chinese city Manzhouli is the embodiment of all these needs. Intended for trade with Russian businessmen, this city of economic cooperation and friendship is fully focused on guests from Russia. In addition to economic opportunities, the city offers the possibility of inexpensive rest in super modern conditions, which is especially critical for the East Transbaikalia, which undergoes economic and social decline. Despite this, comfort and credibility are the last things the guests from Russia think about. Manzhouli has a bad reputation for being the space of deception, aggression and greed of Chinese entrepreneurs. The city is perceived as an elaborate cover, concealing the true image of China as twofaced, incomprehensible and dangerous. No Chinese city in Russia did cause as many complex emotions as Manzhouli; this city is the leader in terms of emotional and heated discussions.

Because of Manzhouli's accessibility and near border location, the dramatic representation of its perception was automatically projected on the neighbouring Siberian cities, negatively marking the "Chinese areas" and the imagined economic potential of the diaspora. Why was the city (which did everything possible to fulfill the requirements of Russian entrepreneurs) perceived as an anti-place, producing only fraud and violence? What unexpressed expectations of Russian entrepreneurs turned out to be decisive for a negative evaluation of the city? To be answered, these questions have to be studied through the attitude of Russians towards Chinese merchants and also taking into account the very urban space of life and commerce, which initiates feelings of danger and distrust among Russian tourists. As will be shown, the projections of the city as a dangerous place can generate the distrust regardless of the city authorities' policy or the behaviour of its residents. 


\section{Russian areas in China: between the objects' cultural diversity and the frontier loyalty of the population}

Throughout the $19^{\text {th }}$ century, Russia played an active role in Russian-Chinese relations, being the chief architect of the north-eastern border and emphasizing the undesirable presence of the Chinese on disputed territories. The tsarist government perceived the settlement of the Chinese in the new Far Eastern provinces as a forced compromise, caused exclusively by the demographic underpopulation in the Asian areas. The ideas of the "Yellow Peril", popular in the media of that time, took the form of a consistent policy of de-sinicisation in the region. This steady policy of removing the Chinese from border areas was a set of measures aimed at increasing control over the Chinese and Korean migration: transfer of the Chinese citizens under the Russian court jurisdiction (1883), deprivation of foreigners of the right to settle in border areas (1886), prohibition to hire foreigners for public works (1910), the elimination of the Manchu enclave in the Amur region (1900), the abolition of duty-free trade in the 50-verst frontier (1913) (Kireev, 2009: 76-77)1. At the same time, Russia gained a foothold in Manchuria: Russian peasants and Trans-Baikal Cossacks settled freely in the border areas of China, so Russian villages and towns sprang up throughout the entire territory adjacent to the Chinese Eastern Railway. Imperial fantasies created the images of "Yellow Russia" as evidence of the Russian colonialist triumph in this part of Asia.

Following the victory of the Bolsheviks in the civil war, the situation changed dramatically. From the Chinese perspective, the pre-war activity of the USSR in China was contradictory: on the one hand, there was economic, moral and military support of the Chinese Communist Party ${ }^{2}$, on the other hand there was the preservation of the tsarist Russian borders and "very strong friendship" with Mongolia and Tuva. Mass emigration from Soviet Russia to Northeast China made the latter hostage in political confrontation with the USSR opponents, which was expressed by the constant violation of China's sovereignty by the Red Army under the guise of combating white troops and by active infiltration of border areas by Soviet intelligence.

In 1949, the USSR turned from a challenging neighbour into a cultural, financial, and technological donor, while confirming Chinese concerns about the priority of geopolitical

\footnotetext{
It should be noted that these measures had minor effectiveness due to the weakness of the administrative apparatus and the immediate economic interest of the Cossacks (responsible for border security) in the Chinese environment. Despite this, the introduction of a biopolitical vocabulary and practices (demanded during the Soviet era) was very important.

2 In many ways, not so consistent and dependent on political state of affairs.
} 
interests over the internationalism ideology among Soviet communists. After the Twentieth Party Congress, relations between the countries had been deteriorating more and more under the influence of a complex of external and internal factors. The period of the Cultural Revolution became an apogee, during which the USSR finally adopted the image of the northern hegemon threatening the territorial integrity of the PRC (Tikhvin, 2008). The militarization of border areas increased sharply (Fravel, 2005: 74) with the corresponding actualization of the mythologemes about the frontier disloyalty of Russian immigrants to China (Peshkov, 2012). Meanwhile, there happened either spontaneous or controlled destruction of Russian heritage sites in the region, perceived as traces of the "century of humiliation". Thus, the frontier population underwent a tense emotional anticipation of a collision, reinforced by restrictions on the movement and the general policy of the socio-political sterility of frontier territories. General facts are widely known: these are the persecution of the Russian and Buryat diasporas, the destruction of the Russian architectural fund and the attempts to ruin the Soviet legacy completely.

In 1949-1986 there was a time for a synchronization of the "frontier socialism" policy both in the USSR and the PRC. The mass migration from the centre and the spread of compulsory primary education in the socialist school marginalized the hybrid culture of the border regions and lengthened the cultural distance between the Russian and Chinese borders significantly. Newcomers with a completely different geographical imagination began to dominate in the region, gradually creating new forms of locality (Bille, 2009; Peshkov, 2014). The opening of borders and the sharp increase in the mobility of the border population led to attempts to invent transboundariness and to redescribe border regions (bastions) in the categories of openness, hybridity and special connections. Unlike Russia, China was interested not only in trade, but also in turning the northeast into a zone of cultural hybridization and schooling, in using Russian cultural models adapted for the Chinese. The region with the experience of frontier socialism, mass migration and long-term isolation again looked for its cultural specificity by joining very diverse elements into a bizarre whole. This active cultural policy was largely aimed at the past, which in this context is a reservoir of symbols that improve the region's investment and tourist attractiveness. The new stage of the Chinese-Russian cooperation brought radical changes in the balance of power between the two countries: now it was not Russia which played a major role as an economic donor and investor, but dynamically developing China which pulled up the Siberian and Far Eastern regions to its orbit. In spite of significant benefits from the border demilitarization, Russian society was not ready for a drastic reversal of roles. 
One of the Chinese respondents in Ergun City area explained to Ivan Basharov the difference between the Russians on both sides of the border by saying that the Chinese Russians are the Russians grown on the Chinese seeds (Basharov, 2009: 305). Continuing this interesting metaphor, one can wonder what is the particular nature of the Russian areas growing on the Chinese seeds. The Russian spaces do not form a common and coherent whole, instead, they are a network of heterogeneous objects connected only by a unifying vector of the Russian footprint re-activation in the new economic situation. Russian signs show the specificity of the region and its peculiarity in the Chinese cultural field: Harbin architecture, phantoms of border cities, urban architecture for ex-Siberian Evenks and buildings imitating churches in "Russian" villages can be seen as the links of one chain. By de-problematizing Russia as a part of the local history, the region almost invents new cultural models which have not existed in its past. Unlike the Russian century, now the cultural model is directly related to the active position of China and its willing to adapt the culture of the northern neighbour to its cultural conditions.

For Hulunbuir, there are two distinctive types of Russian (Siberian) spaces that can be outlined: a trading town and an ethnic village (Table). They are different in their temporal orientation: a trading town symbolizes friendship and cooperation in the cross-border present, while Russian villages and Evenki settlements ${ }^{1}$ present the cross-border past of the region. It is worthwhile noting that both the optimism of economic cooperation and the melancholy of the beautiful past depend on the economy of expecting tourists and buyers to appear.

There are several aspects we can find in common. First of all, these are spaces "not for the dwellers themselves", mostly subordinate to the market logic and the priorities of attracting tourists or investors (Bulag, 2010). This is an absolutely artificial factory of authenticity intended to create commercial images of the friendly past and the happy present. The symbolic objects are piled on one another, creating the effect of an empty space out of time: hotels and Russian steam houses designed in the shape of Orthodox churches, fields decorated with huge Matryoshkas, enormous buildings intended to

\footnotetext{
The relocation of the Evenki reindeer breeders to a specialized settlement of Aoluguya (suburbs of Genhe city in Inner Mongolia) is a very interesting example of re-Siberization policy of the Tungusic peoples of China. The re-Siberization policy is directly connected to the reproduction of Siberian heritage within the nation-building of the Tungusic nations of China. The main purpose of the relocation campaign was to cease nomadism as a backward socioeconomic practice. The relocation spot, Aoluguya settlement, bears a complicated conceptual load: a completely newly built village combines modern family cottages and official buildings in the "Evenki" architectural style. Consequently, the local community divided into the major (app. 190 people) group of Aoluguya residents and the minority of 30-40 attempting to stay in taiga, keeping quite a large herd of deer (700 heads) (Fraser, 2010).
} 
Table

\begin{tabular}{|c|c|c|c|}
\hline Title & Type of space & Temporal orientation & Commercial purpose \\
\hline Manzhouli & Trading city & Present & Trade, tourism \\
\hline Enhe village & Russian village & Past & Ethno-tourism \\
\hline Aoluguya & Evenki settlement & Past of the forest people & Ethno-tourism \\
\hline
\end{tabular}

represent Evenki chums, copies of Soviet monuments accumulated in one spot turn the assigned Russian (or Siberian) space into a "non-place", created for a neo-liberal interpretation of Russian presence as an instrument of improving the investment attractiveness of the region and tourism development.

Secondly, they paradoxically break the connection to the Russian past of the region. It is explained by the two imperatives of the new cross-border reality: representation of cultural diversity and an emphasis on the frontier loyalty of the local population. In this context, the popular ethnography and the official legend of the loyal Chinese border residents designed for tourists are strictly separated and hardly have anything in common. This is a way of avoiding the dilemmas connected to the post-colonial perspective of the Russian presence and concentrating on mutual enrichment. Still remaining a right choice story ${ }^{1}$, the past turns into a pool of symbols enhancing the investment and touristic attractiveness of the region. If we add the influence made on the administrative decision-making by the ethno-tourism market, it would be possible to say that the past turns out to be a hostage not only of the present, but also of the certain economic expectations of the future.

\section{Manzhouli: from a railway workers' settlement to a global city imitation}

Manchuria is the first station of the CER Right-of-Way. Through the major part of its history, it was a small settlement of Russian and Chinese railway workers, resembling more of a village than a town (Urbansky, 2012). The main role-determining factor of the settlement was the border. Depending on the situation, the town was an outstation of the Russian colonial exploration of Manchuria, a Japanese border post, a place of vibrant exchange between the two socialist brother-nations, an important USSR economic assistance organization point or a fortress protecting the region from its Northern neighbour. A new age in the history of the town began on April 16, 1983,

\footnotetext{
The standard role of the past in socialist societies (Zalejko, 1994).
} 
when after the 16 years of economic isolation the cross-border trade between the border regions of the USSR (East Siberian and the Far East) and the PRC (Heilongjiang Province and the Inner Mongolia Autonomous Region) was resumed. Two years later (August 1985), Manchuria-Zabaykalsk city pair was open for the cross-border exchange (together with Heihe-Blagoveshchensk, Suifenhe-Grodekovo and TongjiangNizhneleninskoe) (Bazarov, Ganzhurov, 2002: 59).

Starting from 1991, the bastions of the Soviet-Chinese border finally turned into formal and informal cross-border trade zones. The open border determined the further fate of Manzhouli, which in a very short time managed to grow from a poor provincial settlement into the main pole of development of the Russian-Chinese economic relationships (Zhang Ping-Yu, Ma Yan-ji, Yu Zhen-han, 2002). In the place of the former Chinese-Russian settlement, there appeared a modern trade district, frivolously manipulating quotations from Soviet symbolism and architecture.

Here we deal with an absolutely specific form of the city space russification, with the only purpose to turn a cross-border station into a powerful regional centre of tourism and trade. The East European architecture, the abundance of signs in the Russian language and almost fluent Russian spoken by the locals make it our China, maximally open for a Russian tourist or a businessman. Manzhouli is the major transportation hub of the Russian-Chinese trade (60\% of export to Russia) and a specific phantom of ultramodern life for the Russian and Chinese tourists. The copies of the most famous Soviet monuments stand by church mock-ups, the collection of huge Matryoshkas standing in the open space is combined with quotations from the Persian Gulf trading city symbols, creating the effect of something being out of time and territory. The symbolic space of the city plays the role of Russia for the Chinese and China for Russians, combining the two countries in the space of common (post-) Socialist aesthetics and common economic interests. The fusion of modern architecture, Soviet symbols and global signs (Western brands, American fast food chains unavailable in East Siberia, Chinese goods adjusted to the Russian taste) create the atmosphere of an artificial medium, alien and open for everyone at the same time.

Due to its location and size, Manzhouli is not a global city, but it is important that it is the only attempt to imitate such in the region. It determines both the appearance of the city, the specificity of its new dwellers and the cultural policy intended to emphasize the common (Socialist) past of the region. Its location, adjacent to the border, also determines the seasons of its function: in summer, the city represents Chinese Russia for Chinese tourists, and throughout the rest of the year, this is Russian China for the 
tourists from Russia. In this regard, Manzhouli acts as an intermediary for, at least, three parties: tourists from Russia (cheap shopping in a comfortable environment), tourists from China (real Russia), and the government (a city of intensive cross-border exchange).

All these strategies are interdependent: the absence of guests from Russia makes it difficult to sell the Russian exotics and creates a threat of a financial disaster, should the state get disappointed in this city of friendship and trust. The implementation of these strategies gets more and more complicated by the peripheric location of the neighbouring Siberian regions and the deepening economic problems of Russia, the appearance of new logistic models due to the access to the Western industrial goods (Urumchi-Bishkek-Irkutsk line) and the rapid development of e-trade with China. In this regard, the further fate of the city is directly related to the adjustment of the Chinese economy of expectation (causing the investment re-evaluation of the majority of projects) with the buying capacity of the Siberian periphery, greatly dependent on the gradually reducing subventions from the central budget.

The created urban space of trust and friendship combines the idea of a trading city, the Chinese image of a perfect Russian town and imitation of a global city. Unlike the infrastructure of the memory (Trekhrechie villages) or the factories of the authenticity (Aoluguya), focused on the perfect past with an idea of the future, this type of space symbolizes the future of the region as an important pole of cross-border development. Manzhouli could not be better at symbolizing the new Chinese urbanism, combining the economy of expectation with the transformation of urban spaces into the places of materializing utopia and learning the new models of life, so typical of the Maoist China (Duafang Lu, 2006). Bulag wrote about the urbanistic boom in the Inner Mongolia:

"Cities appear as centres for the industrial miracles and "actions" to happen pointing at the future utopia (...) and are presented by mass media as the picture of modernity (...) and its radically convincing images of a good life, progress and development" (Bulag, 2002: 212).

As for Manzhouli, we deal with a more sophisticated form of an urban space, when the ideas of "a good life, progress and development" are directly connected to crossborder trade and the development of cultural ties. The city symbolizes both Chinese urbanism and Russian traces, bringing them together in a small space intended to present the hope for an economic success. The urban space ties China and Russia 
together in quite a sophisticated way, referring, to a certain extent, to the Russian imperial urbanism traditions of the early $21^{\text {st }}$ century. The city centre is divided into six parallel major streets (avenues) with monumental architecture and geometrically aligned passages. In this regard, Manzhouli harmonically complies with the Russian colonial tradition of the new urban CER space of the early $20^{\text {th }}$ century. The semitowns - semi-villages were opposed to the idea of an imperial city with its straight avenues, big houses and shopping centres. The picture of this image is Harbin city centre, and its repercussions can be seen in the centre of China and the old Russian part of Hailar.

A perfect city is the one that managed to break its connections to the regional traditions, to overcome the past and to look into the future. The irony of the situation is that the neoliberal future shaped in the Soviet monumental architecture moulds, tries to overcome the Russian model of a semi-village settlement, which prevails in the region. In this context, the question of representing the urban past of Manzhouli was resolved in favour of the two main aspects of the regional historical policy: the reproduction of the Russian culture signs (imperative of regional diversity) and the elimination of any traces of real presence in the city (imperative of frontier loyalty of the local population).

\section{"Chinese" as disturbing: the semantics of the negative reputation of the city}

In 2010, Siberian newspapers and Internet portals featured specific cases of physical aggression in Manzhouli markets in a mythical scale and unexpected context of a waking dragon. The scale and the context of the cases described presented them as something more than a report on the exotic behaviour of individual traders in the border city with its anonymity, the atmosphere of easy money and the hedonistic hope of round-the-clock entertainment. In addition to the Russian attitude to Oriental traders well-described in the literature, it would be possible to observe a peculiar recognition effect: the cases described became a symbol of the city-market, turning the city of trust and friendship into a space of deception and aggression infecting the entire transboundary space. The residents of Irkutsk and other Siberian cities transferred these stories to the Chinese segment of the local market, expecting the awakening of the Chinese as the candidates for power in the city. A 40-year-old resident of Irkutsk expressed his concern about the awakening of China, "Everyone says that it is not safe in Manchuria. The Chinese have become completely brutal here like in Manchzhurka. 
They do what they want in the market. They can hit if you do not buy ...”. Internet forums of entrepreneurs presented Manchuria as a danger not only for Siberia, but for China as well. In that way, a person with the username irina saw the danger of the city even for China, "By the way, such criminal acts are taking place only in Manchuria. It's like a "black hole". Deeper in China, everything is like in the good old days. Let us hope that the Manchurian infection will not spread throughout China ${ }^{l}$ ".

What is the reason for distrusting the city of friendship and cooperation? It can be assumed that these were the spatial aspects (a trade city with a border localization) which lead to unexpectedly emotional experiences of cultural, civilizational and geographical barriers by the guests of the city. First of all, staying in the ambivalent zone of the border city activates Russian ideas of the Asian frontier as a space of danger and undesirable meetings. These ideas may lead to a gap between experience and representation and such possibility should not be underestimated. The second barrier is the Asian market of the Chinese type, directly connected with the negative stereotypes of Chinese traders and the hidden threat of Chinese economic domination. The third important aspect is the challenge of the border city-shop window, affecting at least three important representations of Russian people at the same time: about the vector of modernity in the region, the very possibility of the city-market and the prospects for cross-border development with China. All these challenges largely determine the semantics of the urban space development and the consistent doubts about the ability of the city to organize profitable exchange.

A good illustration of the gap between experience and its representations can be the contrast between the daily experience of the guests and the image of a dangerous and inhospitable city created by them. All the respondents emphasized the potential danger of staying in Manchuria and having business there, and from their point of view the city-market created danger both on the night streets (mugging and theft) and on the marketplaces (deception and aggressive behaviour of traders). Cases of fraud and other crimes have taken place indeed, but to call Manzhouli a life-threatening city would be an obvious exaggeration. The gloomy picture of the dangerous city was also contradicted by the respondents' behaviour. Until early 2015, all the restaurants and nightclubs of the city were filled with happy people who freely enjoyed the anonymity of the border space in terms of parties and free sex. The Chinese and the Russians had rest in the same places, often in common groups of friends. But the

Manchzhuria.ru - the city through tourists' eyes, Available at: http://www.manchzhuriya.ru/viewtopic. php? $=22 \& \mathrm{t}=86$ 
representations of this experience in interviews, in mass media and on the Internet forums were surprisingly tense, gloomy and disturbing. The dangers and cases of deception that were waiting everywhere are constantly mentioned. Describing the Asian city-market as a place of deception, hypocrisy and aggression, the respondents presented themselves as heroes who withstood a serious test. This alternative memory not only conceals the real experience, which is impossible in the place of permanent residence for various reasons, but also reproduces the important for the Russian culture mythologeme of the Asian frontier as a place of facing danger and the unknown ${ }^{1}$. It can be assumed that this mythologeme makes a clear dividing line between us and them, carrying out integrative functions. Creating an imaginary community of normal people in an abnormal place (at the border), it includes all the diversity of Russian-speaking representatives of frontier capitalism into the process of symbolic reproduction of the border-bastion: tourists who came to buy fur coats, the Dagestanis running an underground casino in Chita, madams from Irkutsk who came to buy underwear for sex workers, a hospital administrator from Ulan-Ude who buys goods for a store in her home village, shuttle traders from the nearby villages, actors from Donetsk, former prisoners and former military men from Transbaikalia suddenly become a whole that is threatened by Chinese aggression in this representation.

Distrust of Chinese partners creatively connects the Russian colonial tradition of demonizing Chinese traders with the experience of small-scale retail trade globalization in Siberia. The stereotype of the Chinese entrepreneur as an economic predator and deceiver created in tsarist Russia by writers and journalists, took more contemporary forms after 1991, turning the former workers of socialist enterprises into tenacious Asian traders: isolated, incomprehensible and potentially dangerous. These were the discourses of the civilizational gap and amateur culturology of journalists that did not allow to see very similar phenomena caused by the border management system collapse (demilitarization), reduction in the collective forms of agriculture and difficult adaptation of old industrial facilities to new conditions in the social regress of the border areas of Eastern Siberia and in the long-term process of forcing out labour force from Northeast China (Ericson, 2000; Hassrad et al., 2007). Unlike the representatives of the post-Soviet East, the Chinese are perceived in a very peculiar way of the geopolitical mission, where their positive qualities (efficiency, discipline

In the same way, the collective memory of the Soviet population in socialist Mongolia was focused on a simulated political confrontation with the local Russian population, displacing real memories of work or military service (Peshkov, 2012). 
and modesty) become not only a dangerous manifestation of the insidious plan for economic expansion, but also a cause for dehumanization. In this way T. Holtslener writes about the demonization of Chinese migration in the first two decades of the reform, "Patriotic discourse dominates in the print media. The Chinese are shown as an amorphous mass, alike a moving swarm, ready to swallow helpless hosts, and are metaphorically compared to moving birds, locusts or cockroaches (...). In addition to this predator image, the Chinese are perceived as dangerous bodies that can spread infectious diseases among the Russian population (Holtslener, 2009: 108).

Due to the subjective extraterritoriality of the city, these attitudes are in complex relations with the negative image of the Chinese in Manzhouli, complementing each other and creating false empirical evidence of xenophobic attitudes towards neighbours.

As a city-market, Manzhouli, in a sense, is a challenge to the post-Soviet periphery, confronting Russian cultural hierarchies (West-East) with the challenge of economic asymmetry (China-Siberia). In the case of China, non-Soviet socialist modernity is not perceived by the post-Soviet consciousness, which is tied to the opposition of Western and Eastern (Soviet) modernity (Peshkov, 2010). In this context, the existence of a supermodern city on the other side of the border is perceived not so much as the success of China, but as a painful humiliation of Russia. Manzhouli is identified with everything new that is perceived as a serious payment for the unsuccessful reforms in Russia - the prowess of Asian traders, economy of abundance in China and manifestation of the joint effort in the success of one country. The inability of Transbaikalia to take advantage of the success is perceived as the result of the Russians' impracticality and the economic pragmatism of the Chinese. Lena, a resident of the border village, expressed her doubts (which, in the authors' opinion, are not an exception) in Manzhouli success in the following way, "They built everything using our money. I remember Manchzhurka as a village that was worse than Zabaikalsk, and now .... We must be careful with them."

In addition to that, the Russian idea of the region's periphery is also projected on Manzhouli, which largely depreciates the efforts of the residents and the city authorities. The city is perceived as a phantom, imitating modernity in the region where it is impossible by definition. Most of the respondents, especially from Eastern Transbaikalia, perceived their stay in the city as a continuation of the geographical captivity that determines the cultural status of the province in relation to the capitals (Moscow and St. Petersburg) and global cities of the world. Russian mental geography unambiguously defines the vector of culture and development from the West to the East, and in this perspective the region perceives itself as a zone of economic and cultural 
decline remote even from Siberian cultural centres. The very stay in Manchzhurka ranks a person in a modest and low-status segment of small-scale trading. The respondents did not understand non-utilitarian reasons (purchase of goods) for staying in Manchuria and explained the paths of random visitors (from central Russia, Eastern Europe and the Baltic States) to themselves as an almost impossible arriving in a remote place. Sergey, the driver from Petrovsk-Zabaykalsky expressed this approach very accurately by asking my friend and me, "So you are not doing well if you came here"? In this perspective, Transbaikalia, as a space of new poverty, and Manzhouli, as the city-market with a "lack of culture", are equally confined in the geographical captivity of peripherality.

Distrust of the city-market has deeper roots and is largely connected with the overlapping of the idea of the city and the market in one space, which is largely alien to the Russian urban culture, subordinating the markets to the city in the form of fencing in a specific place or their removal beyond the city limits (Humphrey, Skvirskaya, 2009). In the article "Traders, 'Disorder' and 'Citizenship Regimes'”, C. Humphrey linked the attitude of Russians towards commerce and traders with their ideas of disorder. ${ }^{1}$ Two decades that have passed since the time described in the article has not changed social attitudes dramatically. Moreover, the Orientalist projection of the disorder in Asian trade started being perceived as the internal (ethnic market segments) and external (Asian trading platforms as zones of deception, duplicity and easy money) experience of most Russians. Analysing the relationship between the classic metaphors of the city and the Russian urban modernity, Elena Trubina demonstrates an absolutely negative interpretation of the metaphor of market: "Our market is more associated with oriental savagery, visiting traders and 'disorganized trade'. The problematic unanimity, with which ordinary residents, intellectuals, and the authorities resort to the so-called metaphor of the market, is expressed in numerous complaints and judgments. In this way, residents of a suburb of St. Petersburg complain to reporters about rampant street sales of cheap consumer goods by "the immigrants from the southern republics, who are probably staying in the territory of the Russian Federation illegally.” The authors of the complaint, without a moment's hesitation, "blame" the newcomers in thefts that have become frequent in the suburbs, and even consider them to be the cause of "domestic extremism” among the local residents." And then she adds, "Market' as a metaphor for the abundance of opportunities and attracting variety, transforms into

Market space and places of border crossing are most often associated with disorder (Humphrey, 2010: 113). 
an emblem of unfamiliar and alien, which lurks for everyone who does not care about the boundaries of their community "in a patriotic way” (Trubina, 2010).

In this perspective, disorder is the essence of the city-market, regardless of its appearance; it is immanent in place and in many respects is its derivative. It is the lack of order that turns anxiety into a basic distrust of the city - the market for cheap goods as an alternative to the post-Soviet city.

\section{The problem of reputation in an antagonistic cultural environment}

Let us try to sort through the mechanisms of deception in the city. A trap of distrust was a problem of the city from the moment it became a cross-border market town. The goal of the city was to solve problems with trust: an adapted symbolic field, the spread of the Russian language and the possibility to pay in roubles should create a comfortable environment for business and leisure. But, as it was said at the beginning of the article, trust is the last thing that Russian guests in Manchuria think about. Almost everything is worrying: a sleepless city in the neon light against the background of the ruins of the Soviet Trans-Baikal region, the quality and quantity of goods, the Chinese standards that do not comply with Russians, the authenticity of Chinese prices, crafty amiability or, on the contrary, sincere anger of Chinese traders, odd Chinese vodka disguised as Russian, Chinese food and even Chinese prostitutes ${ }^{1}$.

Most of these problems are typical of every post-socialist trading platform or overseas trip to a cheap Asian resort. In the first case, the lack of procedures, common standards and quality control allows for a simultaneously rapid decline in prices and gives rise to risks of poor-quality purchases. In the second case, the consent of the state for indulgences for foreigners (informal currency exchange, unconcealed prostitution and facilitated entry) makes the stay more comfortable, but also creates space for fraudsters and criminals. In this perspective, many problems with trust have an absolutely rational explanation: a large variation in size (Chinese factories use similar names on the European and Chinese scale), misunderstanding associated with the language barrier, and energetic trading style in the markets of north-eastern China can create a sense of Chinese readiness to make money at any cost. The deceptive similarity of the city to Siberian cities played a large role: despite Russian inscriptions, variations of Russian cuisine and Russian music in restaurants, Chinese standards, certificates

There are stories that in Manchuria, they "palm off" under-age prostitutes and then bring the police. The lack of examples of foreigners criminally punished for contacting minors in the region did not stop the storytellers. 
and procedures for providing medical care are significantly different. Together with the language barrier, it created a sense of poor quality that could not compensate for low prices. The fever of the border town also played a certain role: many service centres took on any order (without following the procedures or without any qualifications). In this perspective, most of what is called deception is a misunderstanding, a different emotion of selling, attempts to keep the customer at all costs, and of course mediocre attempts to deceive "rich" Russians.

Though the biggest objective problem clearly lies on the side of the guests: it is balancing of Russian businessmen between the fear of losing and the hope of earning money in the space the feelings of danger and anxiety were projected into. The fear of losing makes you look for your Chinese, the hope of earning creates distrust and suspicion that your Chinese offer unreal prices. This creates an insoluble contradiction between the attempt to solve problems through acquainted Chinese and the search for "real Chinese prices" hidden from Russian entrepreneurs by new Chinese friends (lack of confidence in the ability to organize access to the cheapest prices). At the same time, these strategies strengthened determination of the Chinese sellers - knowing that guests from Russia would always be unhappy they sought to sell goods by any means. It can be assumed that it is not so much the problems that guests from Russia have to solve, but the ways to read them that are unique. Universal problems of border trade were formulated in a dictionary of distrust towards people, the city and border localization.

The Chinese and Russians agree that in Manchuria one may encounter dishonest trade and aggressive behaviour, but this is explained by different reasons and in completely different perspectives. For the Chinese, cases of deception are a fixable and temporary consequence of the wonderful opportunity to earn money for a large number of people. The priority of development over security and consent to a certain grey zone in the first phase of creating an economic centre formed the image of a city of success and neoliberal hope for success. Therefore, the region has long perceived Manzhouli as a symbol of success and the correct model of cooperation. The scale of the phenomenon was significantly different. For the Chinese, deception was a matter of a small number of merchants and a consequence of poor awareness (sometimes naivety) of Russians, who should simply carefully distinguish small groups of bad Chinese from the majority of normal ones. Such perception of the problem of trust determined the solution. The idea of a Chinese friend (a partner who solves problems on-site) has very quickly become a profession for a large number of intermediaries. And besides 
the Chinese, the Mongols from Inner Mongolia and the Shenekhen Buryats that were perceived by the Zabaykalsk citizens as almost their natives have become local guides. They value their special status and use it extremely responsibly. Critical remarks about them are rare, they are hardly perceived as a danger ${ }^{1}$. The state joined the spontaneous solutions to the problem of trust: in response to complaints of cases of fraud in the markets, the city administration created a network of telephone numbers of police officers who speak Russian and issued informational booklets on security measures for guests of the city.

The taken measures did not resolve trust issues and were ignored by Russian guests. First of all, because the ratio of deceiver and honest merchants was perceived quite differently: a certain degree of hypocrisy was attributed to all the Chinese. Noting the presence of good Chinese, who became such because of the benefits of friendship with the Russians or because of individual decency, everyone pointed out the predatory nature of a Chinese entrepreneur. In this perspective, the negative information is perceived as confirmation of the accepted negative image. For Russians, cases of deception are the norm of the Chinese market. It is noteworthy that the undoubted fact of the opportunity to earn money for a huge number of small entrepreneurs is very rarely verbalized and is almost unnoticeable against the background of negative examples. This melancholic view is associated both with the traditional Russian reading of the space of the Asian city market as a place of deception and profit, and due to the clear priority of security over development. The solution to the trust issues was cooperation with the good Chinese, a group of entrepreneurs with an impeccable reputation and the emergence of Russian intermediators. In both cases, the adopted solution model only brought the problem to a new level. The presence of a small group of good Chinese clearly marked the city as a place of deception and danger. Russian companies losing to Chinese intermediators in the city were simultaneously stronger in the Russian information field and aggressively emphasized the general distrust in the Chinese as the last hope to retain their segment of the services market.

The above example shows a reputational problem directly related to trust in an antagonistic cultural environment. Reputation helps participants of the exchange to reduce information costs and risks associated with acquiring low-quality goods or

\footnotetext{
One of my respondents, the Chinese Mongolian Chingiz, said that the Russians did not notice the drama of the Mongols from mixed families: "I am a Mongolian with a Chinese face, this is difficult. It is good that the Russians do not notice this." It may be noted that Chingiz consciously or unconsciously differed from the Chinese "helpers." He was more restrained, tactful and calm, which was noted by his Russian clients as positive features related to the fact that he is not Chinese.
} 
agreeing to higher prices. But its creation in a situation of mass distrust requires the emergence of a fictitious small community of good Chinese, allowing guests of the city to implement economic strategies without abandoning the alarming frame of perception of the city. As was shown above, it was a trap that paradoxically reinforced the disturbing perception of the city. In this perspective, the problem of trust is unsolvable, since each new decision gives rise to a new round of mistrust. The combination of anxious perception of the place and the market-city with quite aggressive strategies for finding real prices led to a constant spiral of frustration and mistrust. Spatial projections and fear of the Chinese craftiness turned out to be stronger than the idea of a cross-border machine of economic growth in the region.

\section{Conclusion}

China implements a model of reforms, in which the features of transitional society are preserved for an unlimited period (Naughton, 2007), but the social responsibility of the state is consistently transferred to the area of private responsibility of citizens (Bhalla, Shufang Qiu, 2010). This creates a field for hybrid strategies for the development of border areas, when the goal of the state policy is not only the modernization of industrial structures, but also the orientation of border areas towards the Russian and Mongolian markets. The problem with this model lies in its complete submission to the economy of expectations and in apparent vulnerability in the event of change in the possibilities of the neighbouring locomotive region. The weakening of the rouble, the reduction of subsidies and the general uncertainty about the future of Eastern Siberia turned out to be more dangerous for Manzhouli than for the Siberian regions. The inability to implement the city's declaration of trust and friendship also played a significant role in the decline of the city. Long before the serious economic problems of Russia, Manzhouli was described as a space of deception and aggression. In addition to the objective reasons listed in the article that are related to the peculiarities of trade in terms of subjective extraterritoriality, the main reason was the triple disagreement of Russian clients: with the border city shop-window of Chinese success, with the market-city and with the creation of a border pole of development. Despite the real and rather positive experience of contacts, public representations of the city of friendship and trust were subordinated to the difficult process of adaptation of the residents of Russia to the end of the Russian century in this part of Asia.

The article shows that, in addition to the objective criteria, subjective factors associated with the experience of the Russian colonial policy and the legacy of the 
smooth infrastructure of the Soviet border, as well as the rejection of the manifestation of success in the former Russian territory play a significant role in choosing a convenient place of trade and leisure. In this perspective, the marginalization of Manzhouli is derived from the existing consensus of the priority of the post-Soviet security perspective over the idea of creating a joint machine of economic growth in the region. It can be assumed that the success of cooperation at the new stage of development of the Siberian regions will require rethinking of the existing spatial (periphery that is dependent on the centre), border (protection from Chinese migrants) and economic (impossibility of good cooperation) mythologemes of the post-Soviet consciousness.

\section{References}

Basharov, I.P. (2010). Russkie Vnutrennei Mongolii: kratkaia kharakteristika gruppy [Russians in Inner Mongolia: a brief description of the group]. Bazarov, B.V. (ed.). In Aziatskaia Rossiia: migratsiia, region i regionalism $v$ istoricheskoi dinamike [Asian Russia: Migration, Regions and Regionalism in Historical Dynamics]. Irkutsk: Ottisk, 301-307.

Bazarov, B.V., Ganzhurov, D.P. (2002). Rossiisko-kitaiskie otnosheniia i rol' regionov Vostochnoi Sibiri v ikh razvitii (1989-1999) [Russian-Chinese relations and the role of the regions of Eastern Siberia in their development (1989-1999)]. Irkutsk: Ottisk, $131 \mathrm{p}$.

Bhalla, A.S., Shufang, Qiu (2009). Poverty and inequality among Chinese Minorities. London New York: Routledge. 204 p.

Bille, F. (2009). Cooking the Mongols/Feeding the Han: Dietary and Ethnic Intersections in Inner Mongolia. In Inner Asia, 11 (2), 205-230.

Bulag, U.E. (2002). From Yeke-juu league to Ordos municipality: settler colonialism and alter/native urbanization in Inner Mongolia. In Provincial China, 7 (2), 196-234.

Bulag, U.E. (2010). Seeing Like a Minority: Political Tourism and the Struggle for Recognition in China. In Journal of Current Chinese Affaires, 41 (4), 133-158.

Duafang, Lu (2006). Remaking Chinese Urban Form: Modernity, Scarcity and Space, 1949-2005, London and New York: Routledge. 204 p.

Ericson, R.E. (2000). The Post-Soviet Russian Economic System: An Industrial Feudalism? In Tuomas Komulainen and Iikka Korhonen, eds., Russian Crisis and its Effects. Helsinki: Kikimora Publications, pp. 133-166.

Fravel, M.T. (2005). Regime Insecurity and International Cooperation. Explaining China's Compromises in Territorial Disputes. In International Security, 30 (2), 46-83. 
Fraser, R.F. (2010). Forced relocation amongst the Reindeer-Evenki of Inner Mongolia, In Inner Asia, 12 (2), 317-346.

Hassrad, J., Sheehan, J., Zhou, M., Terpstra-Tong, J., Morris, J. (2007). China's state Enterprise reform. From Marx to market. London: Routledge. 272 p.

Holzlener (2009). Vostochnaia poristost': antropologiia transgranichnoi torgovli i kontaktov na rossiiskom Dal'nem Vostoke [Eastern openness: anthropology of crossborder trade and contacts in the Russian Far East]. In Oikumena, (3), 102-111.

Humphrey, K. (2010). Postsovetskie transformatsii v aziatskoi chasti Rossii [PostSoviet Transformations in the Asian Part of Russia], Moscow: Natalis, 382 p.

Humphrey, C., Skvirskaya, V. (2009). Trading Place: post-soviet container market and the city. In Focaal: European Journal of Anthropology, 55, 61-73.

Kireev, A. (2009). Spetsifika dal'necostochnoi granitsy Rossii: teoriia i istoriia [The Specificity of the Far Eastern Border of Russia: Theory and History]. In Oikumena, (2), $70-82$.

Naughton, B. (2007). The Chinese economy. Transition and Growth, Cambridge Ma: MIT Press. 544 p.

Peshkov, I. (2012). Politization of Quasi-Indigenousness on the Russo-Chinese Frontier. Franck Bille, Gregory Delaplace and Caroline Humphrey (eds.) Frontier Encounters: Knowledge and Practices at the Russian, Chinese and Mongolian Border. Cambridge: Open Book Publisher, 165-183.

Peshkov, I. (2014). Usable Past for a Transbaikalian Borderline Town. "Disarmament" of Memory and Geographical Imagination in Priargunsk. In Inner Asia, 16 (1), 95-115.

Peshkov, I. (2010). Granitsa na zamke postsovetskoi pamiati. Mifologizatsiia frontirnykh soobshchestv na primere russkikh iz Trekhrech'ia [Locked down border of the post-Soviet memory. Mythologization of frontier communities by the example of Russians from the Three-River region]. Diatlov, V. (ed.) In Migratsii $i$ diaspory $v$ sotsiokul'turnom, politicheskom i ekonomicheskom prostranstve Sibiri. Rubezhi $X I X-X X i X X-X X I$ vekov [Migrations and diasporas in the sociocultural, political and economic space of Siberia. At the turn of the $19^{\text {th }}-20^{\text {th }}$ and $20^{\text {th }}-21^{\text {st }}$ centuries]. Irkutsk: Ottisk, 601-616.

Tikhvinskii, S.L. (2008). Vospriiatie v Kitae obraza Rossii [Perception of Russia in China], Moscow: Nauka. 244 p.

Trubina, E. (2010). Dzhungli, bazar, organism i mashina: klassicheskie metafory goroda i rossiiskaia sovremennost' [Jungle, bazaar, a body and a machine: the 
classic metaphors of a city and the Russian modernity]. In Neprikosnovennyi zapas [Untouchable Reserve], 2 (70), Available at: http://magazines.russ.ru/nz/2010/2/tr20. html.

Urbansky, S. (2012). A Very Orderly Friendship: The Sino-Soviet Border under the Alliance Regime, 1950-1960. In Eurasia Border Review Special Issue on China's Post-Revolutionary Borders, 1940s-1960, 35-53.

Zalejko, G. (1994). Soviet Historiography as "Normal Science". Jerzy Topolski (ed.). In Historiography between Modernism and Postmodernism. Contributions to the Methodology of the Historical Research, Amsterdam-Atlanta, GA; Rodopi., 179-190.

Zhang, Ping-Yu, Ma, Yan-ji, Yu, Zhen-han (2002). Border port Manzhouli: Urban Function and Space Development. In Chinese Geographical Science, 12 (4), 315-320.

\section{Испытание «дружбой»: драма «китайскости» в пространстве приграничного города}

И. Пешков

Университет им. Адама Мицкевича в Познани Польша, 61-712, Познань, ул. Wieniawskiego, 1

На материалах Манжоули анализируется роль фронтирной урбанизащии в массовом осмыслении китайской миграции и роли Китая в регионе. Анализ построен на основе двух серий (2013 и 2014) полуформализованных интервью с жителями города и туристами из России и Китая. Статья показывает, что успех сотрудничества на новом витке развития сибирских регионов будет требовать переосмысления существующих пространственных (периферия, зависимая от иеентра), приграничных (защита от китайских мигрантов) и экономических (невозможность беспрочгрышного сотрудничества) мифологем постсоветского сознания.

Ключевые слова: фронтирный урбанизм, «китайскость», оспариваемые пространства, миграция.

Научная специальность: 22.00.00 - сочиология. 